\title{
Relationship Between Financial and Real Sectors: Implications for Stable Economic Development (Evidence from Thailand)
}

\author{
Muhammad Azhar Khalil ${ }^{1} \&$ Santi Chaisrisawatsuk ${ }^{1}$ \\ ${ }^{1}$ Graguate School of Development Economics, National Institute of Development Administration (NIDA), \\ Bangkok, Thailand \\ Correspondence: Muhammad Azhar Khalil, Graguate School of Development Economics, National Institute of \\ Development Administration (NIDA), Bangkok, Thailand. Tel: 66-649-838-936. E-mail: makraoh@ gmail.com
}

Received: May 13, 2018

doi:10.5539/ijef.v10n6p204
Accepted: May 29, 2018

Online Published: May 30, 2018

URL: https://doi.org/10.5539/ijef.v10n6p204

\begin{abstract}
The real sector of an economy is the key section as activities of this sector persuade economic output and is represented by those economic segments that are essential for the progress of GDP of the economy. The sector generates better outcomes if accompanied with a healthier financial system; thus, advancement of financial sector is a means for the growth of real sector. The study in this paper explores the relationship between financial and real sectors of Thailand with the volatility analysis of GDP caused by development of financial market. The GARCH Model, Johansen-Juselius (1990) co-integration test, vector error correction model (VECM), and Granger causality testing approach was employed on time series data over the first quarter of year 1993 until the second quarter of year 2017. Consistent with past studies, both the elements of capital market (i.e. bonds and stock markets) and the money market (i.e. credit to private sector by banks) bears a positive relationship to the GDP, our results shows that both markets help promoting economic growth. We can infer that differences in financial markets' composition and institutions do matter, as these three major sections - bond market, stock market, and banks- do not simultaneously develop and grow, but at a different level of their growth they complement each other. Our findings suggest that there exists inter dependency between real and financial sector's technologies which in turn enlightens the effect of financial market development on the GDP growth.
\end{abstract}

Keywords: financial sector, real sector, stock market capitalization, bond market, volatilities, GARCH Process

\section{Introduction}

\subsection{Significance of Study}

The mediums through which economic growth accelerate by financial development have been conferred in the literature extensively. Relevant theories can be illustrated through different approaches like optimistic (popular in 1990's and 2000's) and skeptical (common later 2000). In accordance to former approach, a sound financial system is characterized by savings mobilization and allows the resource allocation efficiently (Greenwood, Sanchez, \& Wang, 2010; King \& Levine, 1993), facilitate to invest in high returns portfolios and allowing to have lower risk by investing in different projects (Bencivenga \& Smith, 1991; Saint-Paul, 1992), helps to boost innovative activities and decrease agency costs (Aghion, Howitt, \& Mayer-Foulkes, 2005). Financial innovation causes price change that can give rise to non-degenerate types of participation turnover, i.e. the introduction of a new assets attracts some agents to step in to financial markets to cope their income risk (Calvet, Gonzalez-Eiras, \& Sodini, 2004). In relation to the latter approach, development in financial sector can be a cause of greater systemic risk eventually (Allen \& Carletti, 2006; Kapadia, Millard, \& Perez, 2008; Gai et al., 2008; Wagner, 2007), upset economic capability (Zeira, 1999), application of unproductively greater economic cost (Santomero \& Seater, 2000), substandard lower savings rate (Jappelli \& Pagano, 1994), or the greater labor allocation to financial sector sub-optimally (Bolton, Santos, \& Scheinkman, 2011; Philippon, 2007).

Domestic financial markets in emerging economies are usually under-developed, when there is a liquidity shock, government bond markets would be illiquid and countries starts losing their access to international credit (Gonzalez-Eiras, 2003). Taking into consideration the causal effects of financial sector development, it is needed to consider this sector together with stage of development of other sectors that facilitate in growth process. If financial deepening for instance; leads systemic risk increases due to huge investments' allocation towards risky projects, the production capacity of the economy might be expand in the real sector from technological 
development and demand from efficient firms releases for more finances (Ductor \& Grechyna, 2015). This may decrease the likelihood of crises from systemic risk, raise average growth rates and let the economy stabilize. Apart from these arguments, plenty of skilled labor attracts if greater rent caused by disproportionately rapid progress in the financial sector, therefore, exogenous technological developments in rest of the sectors can restore and allocate the labor optimally. As explained, such as by Murphy, Shleifer, and Vishny (1991) for the growth rates of an economy to be sustained, it is essential to have optimal labor allocation among sectors. Likewise, if advancement in financial sector leads to reduction in savings resulting from interest rates dampening, opposite influence from technological development in real sector leads to increase the interest rates consequent from rise in demand for funds. Accordingly savings in turn, (Ductor \& Grechyna, 2015) depict the level of capital accumulation, subsequent output level and growth rates of the economy. Hence, there is need to understand the importance of linkages between both financial and real sectors that could be significant for the overall progress of the economy to uphold an obvious influence on economic development.

Empirical researches frequently analysis the link among financial sector advancement and real development of the economies as new empirical tools, models and datasets developed and become available. In this study, we would like to explain the momentum through which development of real and financial sectors have an effect on economic growth. So far, as there is least evidence available regarding the importance of development of financial sector for the real sector's development of the economy, we can fill this gap to record its impact and bring the historical impact on lines so governments can develop effective policies accordingly.

\subsection{Background with the Perspective of Thai Economy}

Thailand has showed remarkable performance in both social and economic development during last four decades, changed her status being a low income economy to an upper income economy. Discretely, Thailand revealed so many success stories in growth with persistent strong development particularly during 1980s with remarkable reduction in poverty. The average annual growth rate of Thailand has remained at $7.5 \%$ during boom years from 1960 to 1996 and remained 5\% following from financial crisis in Asian economies from years 1999 to 2005, facilitated to pull thousands of individuals out from poverty by creating lots of jobs. Progresses beside several measures of welfare have stood inspiring, currently many more children are attaining education at higher levels and nearly everyone now a day covered by means of health insurance while various other types of social security plans have prolonged. Later on average growth rate reduced to 3.5\% from 2005 to 2015 with a drop to $2.3 \%$ during 2014 to 2016. Thailand is nowadays running on the track to recovery. As on 2017, growth is expected to reach at $3.5 \%$ and grow further up to $3.6 \%$ in year 2018 .

Substantial decline in poverty have seen over the last 3 decades from $65 \%$ during 1985 to $7.5 \%$ in year 2015 in the high growth phases with the increasing prices of agricultural products. Though, inequalities in different regions and poverty keep posing challenges, with susceptibilities causing agriculture prices to fall down and ongoing deficiencies as a result of uncertain growth of the economy. More than $80 \%$ of country's 7.3 million poor recorded in 2014 who lives in rural zones. Even though inequality has dropped from past 30 years, but within and across regions of Thailand, still crucial and rising gaps in the income and consumption of household can be seen, with the bags of poverty outstanding in the areas of Deep South, North and Northeast.

Thailand has set out its long term goals for the economy in its [20 Years National Strategy Plan (2017-2036)] for achieving the status of being developed country by comprehensive reforms. These reforms will address stability of the economic, human capital investments, equivalent economic opportunities, financial liberalization, competitiveness, sustainable environment, active government administrations and last but not least a healthier financial system to finance, secure and support all these reforms. Current reforms will backed by the financial sector for the implementation and support of big multi-years public infrastructure projects associated to the dual tracking of railway, regulatory developments aimed to improve ease of doing business in Thailand, incorporating State Enterprises Policy Committee to expand state owned enterprises governance, transfer of regulatory oversight of specialized financial institutions to the Bank of Thailand (World Bank, 2017).

\subsection{Statement of Problem}

The real sector of an economy is the key section as activities of this sector persuade economic output and is represented by those economic segments that are essential for the progress of Gross Domestic Product (GDP) of an economy. The sector is crucial for the sustainability of the economy because of its productive capability to meet nations' aggregate demand (Oluwafemi \& Olufemi Adewale Aluko, 2015). The real sector generates better outcomes if accompanied with a healthier financial system; thus, advancement of financial sector is a means for the growth of real sector. One of the key determinants of economic development is the growth of financial sector. Though, because of the wide description and inter-dependence to certain other areas of economic development, 
there is unclear influence of financial advancement on economic development (Ductor \& Grechyna, 2015).

Is it common to say that financial market supports the real sector, the argument could be yes because if the financial market actually setting up and provides services to the real sector whenever real sector needs any kind of financial services like capital, financial sector provides it or if the real sector need services to manage the risks, financial market comes in and provide some equipment or financial tools to manage their risks. Moreover, when the financial sector needs to improve efficiency and reduce cost, financial sector helps to achieve the efficiency. So, if the financial markets do the job, then we can see the link between these two in this case. The real sector needs to take the leading role and financial sector will follow to responds the needs of real sector. If this is not the case, then it will go to another way and the question for us is the financial sector provides something that real sector does not need or the financial sector is going too fast? One of the argument is financial sector is growing but it's not contributing to the real sector and providing some products/services to its own where lot of people want of work in the financial sector because they get good returns even those who could work better in other segments of the economy.

We would like to have equilibrium between these two sectors and sometimes circumstances cause disequilibrium like financial crises 1997 and hamburger crises 2007-2008 both were caused by financial sector. Economic crises in the past basically inflation, energy, unemployment etc. those are the factors leads to economic crises. But the reason we had crises doesn't because we have high inflation or higher unemployment, it is because we have crash in the financial sector. That is why we need to study this problem when financial sector grows, does it mean real sector is growing? Or they have any kind of relationship that we do not understand yet.

The reason we choose Thailand to study this issue is upon getting enough information in terms of the data sets, we would like to consider it separate before and after 1997 financial crises and see if the relationship is different. No one have studied this for Thailand before and we would like to know what would happen if we promote stock market, would it leads to growth in GDP, and many countries are trying to study this relationship.

\subsection{Objective and Motivational Features of Study}

The purpose of this research is to provide evidences about interdependence between financial sectors' indices (specifically; money market and capital market) and real sector of the Thailand's economy which represent by its GDP. Reason why the focus of our study is on financial sector is; since, during the period of financial crisis, mostly this sector remains affected (Kutan, Muradoglu, \& Sudjana, 2012; Stiglits, 1999; Williams \& Nguyen, 2005). Likewise, when significant changes take place in the financial sector, the impact of these changes also affects real sector. As a result, it is very important to evaluate these changes by reviewing both sectors. Four questions we would like to explain raised by this study. First, is there any kind of relationship exists between financial and real sectors? Second, what are the effects of financial market development on the growth of the overall economy? Third, variations of growth whether or not it can be explained by variations in the financial market? The study motivates to contribute new findings to the on hand literature by putting some lights on relationship between desired sectors. After Section 1, Section 2 reflects the cruxes of the empirical literature and conceptual model of the study. However, Section 3 contains the information about details source of the data, methodology and specification of model. Segment 4 is for the results interpretation. Last Section of this paper deals with concluding notes and recommendation of suitable policy.

\section{Literature Review}

\subsection{Review of Literature}

The empirical reviews of literature illustrating the effect of financial growth on economic development, like theoretical studies, follow and determined by two general historical approaches; first one termed as optimistic (mostly admired during 1990s and 2000). King and Levine (1993), Raghuram and Zingales (1998), Levine, Loayza, and Beck (2000) are the representative of this approach. According to this approach, it seeks to justify the financial development and financial innovations as crucial measures for the strength of an economy and to achieve viable economic development. The development of this approach commenced during the period of rapid growth of the global economy in financial sectors' services and its liberalization.

The second approach in explaining the impact of financial growth on economic development, refers to skeptical (popular after 2000s) boomed after the financial crises from 1997-1998 and during 2007-2008. Many possible hazards of financial liberalization were highlighted by this approach. Specifically, after the great crises conclusions from the representatives of optimistic approach were on doubt shed by the studies.

The findings of King and Levine's (1993) re-evaluated through incorporating the models of threshold regression by Deidda and Fattouh (2002), results from their study endorsed the non-linear consequence of financial 
enlargement on the economic development. Employing data set of Raghuram and Zingales (1998), development in financial sector uphold a non-linear effects on economic development revealed by Manganelli and Popov (2013). In addition to these arguments, Cecchetti and Kharroubi (2012) analyses an inverted U-shaped outcome of financial sector's development. The effect of various kind of lending from financial institutions on economic development depends on stage of banking sector's development of an economy (Owen \& Temesvary, 2014).

While working on sample of East Asian countries, Ben Gamra (2009) argues that limited liberalization of financial sector bears significant positive impact on the economic development compare to full liberalization. Kaminsky and Reinhart (1999) found that channels of financial development have plausible negative effect on economic development by triggering instabilities in financial sector. Because of financial instabilities, a positive long-run relationship exist among output and financial intermediation, whereas in short-run the relationship becomes negative (Loayza \& Ranciere, 2006). Rousseau and Wachtel (2011) explain that irrespective of country's stage of development, a positive impact of financial growth get weakens with the passage of time.

Findings of Levine et al. (2000) re-estimated by Beck, Degryse, and Kneer (2014) and their findings shows that a greater financial sector tends to boost development and decreases uncertainties in long-run, however with the short runs' perspective it stimulates development at the expense of greater instabilities. Similar evidences found while directing for endogeneity problems of financial sector's development and employing numerous estimation methods by Arcand, Berkes, and Panizza (2012). Calderón and Liu (2003) argue that the contribution of financial deepening towards growth is more in developing economies compare to developed economies. While examine the European countries' sample, Masten, Coricelli, and Masten (2008) found the same results and describe that developing countries grow more from development of financial sector.

Rioja and Valev (2004) analyze a significant positive impact of financial deepening on economic development. Empirical evidences from the study of Ang (2011) suggest that liberalization of financial sector can leads to slow down the process of technological development resulted from reallocation of talent to financial sector from the modern sector that could be more innovative.

By taking into account the co-determination for development of financial sector and growth of real sector. This study will contributes to the empirical literature and highlight the important implications considering the significance of relationship between financial development and the economic growth of the economy.

\subsection{Conceptual Model}

In accordance with the theory of economic growth (founded by Lucas, 1988; Romer, 1986 and Solow, 1956), initial levels of the GDP, both physical accumulation of capital and the human capital development are key factors of per capita economic growth. The relationship should be positive between per capita economic growth and a level of human capital of an economy because greater human capital is characterized by innovative thoughts that foster rapid economic development. However, per capita economic growth supposed to be negatively correlated with initial level of GDP due to the convergence effect that is with the diminishing rate of capital accumulation, economies have to converge at their level of steady state. Moreover, in many empirical growth models, various other factors like economic, institutional, geographic, and political issues have been incorporated [for a broad survey, find (Durlauf, Johnson, \& Temple, 2005)].

The empirical literature evaluating the effects of financial sector's advancement on economic development taking into consideration the specific sets of control variables relevant to the country's economic stability and the government policy: indicators of fiscal policy, measures of price stability and openness to global trade (find, as explained, Levine et al., 2000), together with the measures of financial deepening. Few years ago, in the growth regression, Arcand et al. (2012) incorporated a quadratic form of development of financial sector and found non-linear association among financial development and economic growth. Theoretical evidences of the non-monotone effects of financial liberalization on economic development could be comprehend in the following arguments:

(1) Development of financial sector leads to a greater economic stability and can increase economic growth. Both financial liberalization and innovation in financial sector are captured by financial development and are the source of a more prosperous economies (Calderón \& Liu, 2003), or could be reason of accumulated systemic risk (e.g., see Gennaioli, Shleifer, \& Vishny, 2012; Wagner, 2007; Allen \& Carletti, 2006). Numerous empirical and theoretical findings on this matter have revealed that financial development is crucial and leads to economic development.

(2) Financial development may reduce economic progress resulted from misallocation of resources. A rapid growth in financial sector produces massive rents and captivates the resources which could ideally be utilized in 
some other sectors (for instance, see Bolton, 2011; Philippon, 2010; Santomero \& Seater, 2000). Poor distribution of resources indicates that both in short term and long term, the desired growth rate might not be possible to attain. For instance, if financial system of an economy practices cream skimming that is a lot of skilled labor who devote their efficiency to the financial sector's development, the rest of the sectors may not progress well due to the unavailability of necessary human capital, caused delays in development and growth.

We confer that both arguments should entail the following statement: "If development in financial sector is accompanied by real sector's development, it can increase growth of the economy". Beside the channels of balanced economic growth, by definition, the entire sectors of an economy have to progress at constant rate. Particularly, financial and the real sectors of an economy should be balanced and move at a proportionate rate. An economy's growth rate of total output remains affected whenever any of these two sectors do not grows proportionately, with the aim to avoid the accumulation of financial volatility, for those sectors that avail financial sector's services, like real sector do, have to develop adequately fast enough to uphold the demands for financial funds. Persistent or growing competition for financial services indicates that the portion of funds to suboptimal and uncertain projects are small or reducing with the passage of time (because less-efficient project becomes profitless when greater demands for funds rises its relative prices). Likewise, due to rapid growth in financial sector, to stop misallocation of resources, the productive industry should develop sufficiently fast to come up with the ability to compete for these resources.

Hence, we develop our hypothesis that there is positive relationship between financial sector and the real sector of the economy if the financial services development is accompanied by the real sector's growth. To test for this hypothesis, we will consider the empirical growth models include in the relevant literature using time series data for economy of Thailand. It is expected that the progress of capital markets and banks could be more crucial for the growth of the country than the industrial economies, implying that developing economies have more opportunity for financial and economic development.

\section{Data Sources, Specification of Model, and Research Methodology}

This segment will provide details about sources of the data, model specification and the methodology that we supposed to use in the study.

\subsection{Sources of Data}

The research organized in this study depend on the secondary sources of quarterly data, perhaps from the quarter 1 of year 1993 to quarter 2 of year 2017. For the authenticity of the results, the data collected for the selected variables from different resources i.e. The Stock Exchange of Thailand, The Bank of Thailand, Thailand's Ministry of Finance and The World Bank (World Economic Outlook) data on Thailand.

The growth of real sector of the economy is represented by GDP as it's extensively used in the recent literature (e.g.: Ductor \& Grechyna, 2015; Samargandi, Fidrmuc, \& Ghosh, 2015; Law \& Singh, 2014). The selection of variables to capture the development of financial sector is a challenging job due to a various reasons. Financial institutions and other agents provide wide-range of financial services. Among all, stock market and banks shows a significant role. So as to capture a true depiction, it is needed to evaluate the different aspects of financial market development, i.e., whether the financial sector of Thailand dominated by stock market or by banks or both. Though, our main objective is to examine the long run relationship. Consistent with the literature, our measures to signify the development of financial sector are the domestic credit to private sector (see for example: Ben Jedidia, Boujelbène, \& Helali, 2014; Beck \& Demirgüç-Kunt, 2009; Masten et al., 2008), Stock market capitalization (see for example: Ben Jedidia et al., 2014; Owen \& Temesvary, 2014; Manganelli \& Popov, 2013; Rousseau \& Wachtel, 2011; Greenwood et al., 2010), Size of LCY T-Bills and Bond Market (for example, see: Thumrongvit, Kim, \& Pyun, 2013; Bjellerup \& Shahnazarian, 2012; Dehkordi, Samerti, \& Dehkordi, 2012).

\subsection{Specification of Model}

Table 1. Description of variables

\begin{tabular}{ccc}
\hline Variables & Abbreviated By & Data Source \\
\hline $\begin{array}{c}\text { Dependent Variable } \\
\text { Gross Domestic Product } \\
\text { Independent Variables }\end{array}$ & GDP & The Bank of Thailand \\
$\begin{array}{c}\text { Domestic Credit to Private Sector by Banks } \\
\text { Market Capitalization } \\
\text { Bonds }\end{array}$ & LOANS & World Development Indicators (WDI) \\
MKTCAP & The Stock Exchange of Thailand \\
& BONDS & The Stock Exchange of Thailand \\
\hline
\end{tabular}

Where GDP is the Gross Domestic Product; LOANS: amount of loan provided by the banks; MKTCAP: Capitalization of Stock Market; BONDS: government bonds and the corporate bonds. 
The stated equation for the model is as follows:

$$
\operatorname{GDP}_{\mathrm{t}}=\beta_{0}+\beta_{1} \text { BONDS }_{\mathrm{t}}+\beta_{2} \text { MKTCAP }_{\mathrm{t}}+\beta_{3} \text { LOANS }_{\mathrm{t}}+\mu_{\mathrm{t}}
$$

\subsection{Methodology}

The study organizes in this work uses time series data in assessing the relationship between real and financial sector of Thailand. It is considered as important to inspect the stationarity of the time series data. It is recognized by employing (ADF) Augmented Dickey Fuller test. Dickey and Fuller (1979) explained the structure in order to working out on test for non-stationary. Hereafter, in brief, the co-integration equation is estimated by employing the test developed by Johansen Juselius (1990), known as Johansen Juselius co-integration test

\subsubsection{Test for Stationarity}

It is essential to inspect the stationary of data in time series models. Dickey and Fuller (1979) introduced the structure for working out on non-stationary of data and it is familiar as (ADF) Augmented Dickey Fuller test. The most considerable aspect of this method is the testing for unit root.

Where,

$$
\Delta y t=\beta_{0}+\beta_{1} t+\varphi_{y t-1}+\chi_{i} \sum_{t=1}^{m} \Delta y_{t-1}+\mu_{t}
$$

$\varphi$ and $y_{t}$ indicates the state of stationarity and the regressors, $\mu_{t}$ is the white Noise, and $\Delta y_{t-1}$ equals $\left(y_{t-1}-y_{t-2}\right), \Delta y_{t-2}=\left(y_{t-2}-y_{t-3}\right)$ etc.. If calculated statistic appears less than the critical value, $Y$, will considered as stationary.

\subsubsection{Test for Co-Integration}

To test for co-integration, the estimation technique used in this study comprises the Johansen Juselius (1990) co-integration test. If the selected variable(s) become stationary at first difference, in that case, Johansen-Juselius co-integration test can be used to examine the results. In which VAR of order $n$ :

$$
Y_{t}=A_{1} Y_{t-1}+\ldots \ldots \ldots+A_{n} Y_{t-n}+B X_{t}+\varepsilon_{t}
$$

Where $\varepsilon_{t}$ representing the innovation vector, $X_{t}$ used as the q-vector of the deterministic variable and $Y_{t}$ is the $\mathrm{k}$-vector [I(1) of time series variables].

Therefore, VAR can be described as following:

$$
\Delta Y_{t}=\rho Y_{t-1}+\sum_{i=1}^{m-1} T_{i} \Delta Y_{t-i} \varphi X_{t}+\varepsilon_{t}
$$

Here we have, $\rho=\sum_{i=1}^{n} A_{i}-I$ and $T_{i}=-\sum_{j=i+1}^{n} A_{j}$

If matrix $\rho$ comprises reduce rank of $(\mathrm{r}<\mathrm{k})$, in that case it would be the $\mathrm{k} x \mathrm{r}$ matrices of $\alpha$ and $\beta$ with rank of $\mathrm{r}$ i.e. $\rho=\alpha \beta$ and $\beta_{Y_{t}}$ is the integrated order of zero. So therefore, matrix can be verified by the mean of reduced rank from that of unrestricted VAR.

\subsubsection{Testing for Error Correction Model (ECM)}

Further, in time series analysis, a type of model is Error Correction Model (ECM) that can directly assess the djustment speed of a left hand side variable to its equilibrium as there is a change occurs in the independent variable. Question retained concerning for the long term relationship is, whether the short term effects are permitted on dependent variable. It is explained by the following specification:

$$
\begin{gathered}
\Delta G D P=\gamma+\alpha \eta_{T-i}+\sum_{i=1}^{G D P} \beta_{G D P} \Delta G D P_{t-i}+\sum_{i=1}^{G D P} \beta_{M K T C A P} \Delta M K T C A P_{t-i}+ \\
\sum_{i=1}^{G D P} \beta_{D C P S} \Delta L O A N S_{t-i}+\sum_{i=1}^{G D P} \beta_{B O N D S} \Delta B O N D S_{t-i}+\varepsilon_{t}
\end{gathered}
$$

Where, $\alpha$ representing the speed at which short run equilibrium is adjusted, $\gamma$ and $\varepsilon_{t}$ is coefficient and the error term. 


\subsubsection{Granger Causality}

Granger (1969) established test for causality which is a hypothesis test in estimating that a time series is important to predict another series or not. As the evidences of co-integration are exists, therefore, it can be represented as following:

$$
\begin{gathered}
y_{t}=\alpha_{1}+\sum_{i=1}^{n} \beta_{i} x_{t-1}+\sum_{i=1}^{n} \alpha_{i} y_{t-1}+\mu_{1 t} \\
x_{t}=\alpha_{2}+\sum_{i=1}^{n} \chi_{i} x_{t-1}+\sum_{i=1}^{n} \alpha_{i} y_{t-1}+\mu_{2 t}
\end{gathered}
$$

Where $\mu_{1 t}$ and $\mu_{2 t}$ represents error terms that are supposed to be uncorrelated. If the lag term $\mathrm{x}$ is statistically different from zero, $\mathrm{Y}$ does caused by $\mathrm{X}$ and reverse is true. Besides, if both lag terms $\mathrm{X}$ and $\mathrm{Y}$ are turned to be different from zero (statistically), it reveals for causality which is bidirectional and elsewhere.

\subsubsection{Generalized Auto-Regressive Conditional Heteroskedasticity (GARCH) Process}

The GARCH model constructed by Engle (1982) can facilitate to explain the financial sector with which volatility might variate, it can be highly volatile in the periods of crises in financial market or global events and become lower volatile in the stages of relatively stable economic growth. This model is particularly suitable when the objective of the study is to evaluate and forecast volatility. In this study, to see the variations of GDP whether or not can be explained by variations in the financial market, we obtain the variance of GDP by estimating a following equation:

$$
\operatorname{err}^{2}{ }_{t}=\hat{\gamma}_{1}+\hat{\gamma}_{2} \operatorname{err}^{2}{ }_{t-1}
$$

After getting the variance of GDP, We run the following OLS regression to obtain the results where the null hypothesis is the volatilities in GDP are not described by the development in the financial sector.

$$
\text { var. } g d p_{t}=\beta_{0}+\beta_{1} \text { bonds }_{t}+\beta_{2} \text { mktcap }_{t}+\beta_{3} \text { loans }_{t}+\varepsilon_{t}
$$

\section{Results and Discussion}

\subsection{Interpretayion of Results}

Statistical results from empirical analysis are further classified into test of stationarity of variables and its short run as well as long run coefficient estimations.

\subsubsection{Testing for Unit Root}

Testing for the stationarity of the variables which are employed in this study, we end it up with the conclusion that the null hypothesis of non-stationary is rejected at $1 \%$ level of significance. Table 1 contains the result of $\mathrm{ADF}$ test reported in appendix.

\subsubsection{Unrestricted Co-Integration Rank Test}

Johansen Juselius (1990) developed one of the important tests for examining co-integration which is useful to measure the symbols and magnitude of long run relationship between variables and to provide marginal values for the stated equation (Equ.2). The co-integration vector becomes normalized at GDP. The results of co-integration equation can be viewed in table 2 in appendix where the computed statistics shows two co-integration equations at a significance level of 0.05 .

\subsubsection{Normalized Co-Integrating Coefficients: At 1 Co-Integrating Equation}

The coefficients of $\beta$ with reference to normalized co-integrating coefficients are indicated in table 3 of appendix with the following equation ( $t$-statistics in parentheses).

$$
G D P=0.177 B O N D S+0.038 M K T C A P+0.091 L O A N S+\varepsilon_{t}
$$

The result indicates that all the variables sustain a positive relationship to the GDP. The results of this study show that a one million baht increase of amount in the capital market by issuing bonds brings 0.177 million increase to the GDP. It is true from the fact that the development of bond market has greater effects for the firms depending more on external credit because the market allows them for a higher diversity of opinion amongst creditors, while retaining some controls in case of bankruptcy that is not permitted by stock market (Maskus, Neumann, \& Seidel, 2005). The bonds market development is positively related to the growth of GDP of the 
economy. It is obvious from the argument that bonds are one of the means by which companies fund their business operations (working capital) and expansion (growth capital). As corporations require an increasing amount of working and growth capital as they grow, needs for financing eventually evolve beyond that which can be stably and efficiently met by the banking system alone. That becomes an important inflection point for capital markets, including both government and corporate bond market, development which has become more urgent as financial regulatory reforms compress banks' willingness and ability to lend. The finding is consistent with the literature on the primary impacts of both governmental and corporate's capital expenditures, that is economic growth primarily comes from technological innovation and improved productivity of labor in the private sector (Thumrongvit, Kim, \& Pyun, 2013b). The same findings have also been produced by (Gennaioli et al., 2012). While there is some debate about the findings and other empirical research shows inconclusive or mixed results depending on the subset of countries and stages of institutional and economic development, the important role of capital markets in economic development is widely accepted.

In respect of the MKTCAP, a million baht increase in stock market capitalization leads to increase in GDP by 0.038 million. It is because stock market is an essential source of funding to the businesses, either from the introductions of stock exchanges or via issuance of new shares. This means that in the presence of more developed capital market, firms can easily get access to the new capital and utilizes the funds in the worthy projects that might lead them to earn more profits. As a result, firms gets bigger and have more value, if the businesses making profits out there, then the economy is growing and that is how it contributes to the GDP. In addition, developments of stock markets are essential for the growth of equity of both businesses and households (Bjellerup \& Shahnazarian, 2012). Our estimation is consistent with the literature largely taking into account the relationship of said variables. A study by David et al. (2014) in a cross-country analysis stating both stock markets development and banks found to be positively related to the real output of the economies.

Talking about the loans provided by the banks (LOANS), our findings suggest that 1 million baht increase in the loan provided by the banks raises GDP by 0.090 million baht. The positive relationship between loans and GDP can be explained from a theoretical perspective in several ways. Positive effects might come directly from improved allocation of capital and risk sharing. More importantly, development of money market can stimulate growth indirectly. Increased competition among financial institutions leads to reduced cost of borrowing and higher efficiency (Levine, 2000). This stimulates the demand for funds and increases the size of domestic financial markets. Money market also facilitates the growth process through improvements in the institutional framework, i.e. improved regulation and corporate governance that augment the overall stability and reduce problems of asymmetric information. Consequently, the effects of well-established banking system should be reflected through size-based measures of financial development. The evidence is consistent with (Masten et al., 2008), they argue that credit to the private sector plays important role as developing countries benefits considerably more from money market development and it is a key driver for economic growth. The same results were found by (Thumrongvit et al., 2013b).

\subsubsection{An Analysis of Short-Run Dynamics}

A category of multiple time series models is Error Correction Model (ECM) that can directly estimate the speed of adjustment of a dependent variable to its equilibrium as there is a change in an independent variable. ECM is one of the ways to explain the multivariate relationships characteristics of economic series.

The Error Correction Model identifies the possibilities of short run relationships. The results of ECM in table 4 in Appendix show that value of Error Correction Co-integration's coefficient equation is 0.22 . It indicates that $22 \%$ of disequilibrium corrected in each quarter. All variables are correlated to the GDP in different directions at different quarters lag. The summary of correlation of variables to GDP is explained in the following table.

Correlation of Variables to GDP

\begin{tabular}{ccc}
\hline Lags & Positively Correlated Variables to GDP & Negatively Correlated Variables to GDP \\
\hline At one quarter lag & MKTCAP, LOANS & BONDS \\
At two quarter lag & BONDS, LOANS & MKTCAP \\
At three quarter lag & MKTCAP & BONDS, LOANS \\
At four quarter lag & LOANS & BONDS, MKTCAP \\
At five quarter lag & LOANS & BONDS, MKTCAP \\
\hline
\end{tabular}

\subsubsection{Granger Causality Test}

A test that explains the causality among variables was developed by Granger (1969). The findings of granger 
causality test are explained in Table 5 (see Appendix). The results clearly demonstrate that the null hypothesis (does not granger cause) is rejected for 1: MKTCAP and GDP, 2: GDP and LOANS, 3: BONDS and MKTCAP, 4: BONDS and LOANS, 5: MKTCAP and LOANS at 5\% level of significance. In the case of BONDS and GDP, GDP and BONDS, GDP and MKTCAP, LOANS and GDP, MKTCAP and BONDS, LOANS and MKTCAP, there is acceptance of null hypothesis.

\subsubsection{Generalized Auto-Regressive Conditional Heteroskedasticity (GARCH) Process}

A GARCH model constructed by Engle (1982) can facilitate to describe the financial markets in which volatility might change, it can be more volatile during the periods of financial crises or global events and become less volatile in the periods of relatively stable economic growth. This model is particularly suitable when the objective of the study is to evaluate and forecast volatility. In this study, to see the variations of GDP whether or not can be explained by development in the financial market, we estimate the variance of GDP by employing GARCH $(1,1)$ model. After getting the series of variance of GDP, results of Johansen Juselius Co-integration test confirmed that there is no co-integration equation(s) exists between the variables. Therefore, simultaneous estimation of GDP variance and the associated volatilities caused by financial variables estimated by using the following equation;

$G A R C H=C_{1}+C_{2} * R E S I D(-1)^{\wedge^{2}}+C_{3} * G A R C H(-1)+C_{4} * D(B O N D S)+C_{5} * D(M K T C A P)+C_{6} * D(L O A N S)$

Results of the above estimated equation are stated as following (also reported in table 6 of Appendix).

\begin{tabular}{ccccc}
\hline Variable & \multicolumn{1}{c}{ Coefficient } & Std. Error & z-Statistic & Prob. \\
\hline \multicolumn{5}{c}{ Variance Equation } \\
C & $1.42 \mathrm{E}+09$ & $4.64 \mathrm{E}+08$ & 3.072737 & 0.0021 \\
RESID(-1)^2 & 0.294486 & 0.119961 & 2.454858 & 0.0141 \\
GARCH(-1) & -0.116023 & 0.088298 & -1.313988 & 0.1889 \\
D(BONDS) & 440.7658 & 2061.457 & 0.213813 & 0.8307 \\
D(MKTCAP) & -301.5612 & 211.8304 & -1.423597 & 0.1546 \\
D(LOANS) & -789.0988 & 1862.573 & -0.423661 & 0.6718 \\
\hline
\end{tabular}

According to the results, the coefficients, its z-statistics, and probability values of all the regressors are statistically insignificant that led to the acceptance of null hypothesis for all the explanatory variables which is none of the variable causes the variations in GDP. As per our estimation of the Thai economy, it follows that as the size of the capital market in terms of issuance of bonds and stock; and the money market in respect of providing loans by the banks increases, it will not causes the GDP to fluctuate overtime. While working on the sample of Turkish economy, similar results were identified by Alper and Anbar (2011). The evidences in this study suggest that one essential element for the dampening of recessions and to stimulate the economy is the well-developed financial system that allows the economy to have more stable events. Though, both the stock and the bond market can decrease volatility by allowing, for example, aimed to have better risk management in firms. In this respect, our results on financial sector's development add flesh to Rousseau and Wachtel (2011) findings with regards to smoothing effects of financial market development on real sector's productivity.

\section{Conclusion and Recommendation}

\subsection{Summary}

In this study, we have examined (i) the relationship between financial and real sectors of the Thai economy, (ii) the effects of financial market development on the growth of the overall economy, and (iii) to capture the negative impacts of the financial sector's development, we analyzed that variations in GDP whether or not explained by the development of financial sector in terms of its expansion in size. The empirical tools employed in this study based on the technique of Johansen Juselius Co-integration test, Error Correction Model, Granger Causality and GARCH process. Normalized Co-Integration Coefficient: 1 Co-integrating equation confirms that both the elements of capital market (i.e. bonds and stock markets) and the money market (i.e. credit to private sector by banks) bears a positive relationship to the GDP. Consistent with past studies, our results shows that both markets help promoting economic growth.

\subsection{Conclusion}

Previous studies have mostly dedicated its focus on the positive role of development in banking sector and stock market on economic growth. The study in this paper enhances the analysis by adding bond market as third key 
element of the financial market, a factor that has largely been ignored in the literature. Our study contributes to the empirical literature with the findings (i) that there is a positive relationship between economic growth and the expansion of stock market, (ii) that there is a positive relationship between bonds market and economic growth, (iii) the contributing role of bank credit to economic growth is also positive with the development of financial structure of the country from the period 1993 to 2017 covered in our study, and (iv) as far concerned the variations in GDP caused by the financial market development, in our results, there are no evidences found that any of the three components of financial sector causes volatilities to the GDP of the economy.

\subsection{Recommendation}

The findings endorses earlier studies: the expansion of stock market together with development in financial structure of the economy contributes to the economic growth via improved labor productivity and technological innovations in the private sector (Ductor \& Grechyna, 2015). However, in this study we have not dealt with the types of bonds (i.e., floating rates, fixed, or zero-coupon bonds) or bond derivatives (i.e., bond futures and/or options), it is due to the reason that bond market complements banks and stock market in deepening the financial sector of the economy. For example, in the bond market absence, banks are likely to become over-capitalized and it may leads banks to make sub-optimal or misallocation of loans. Alternatively, a market with a well-established bonds system, where bank's investment in bonds market, and in so doing, decreases information asymmetries, which can facilitate to promote efficient usage of funds. That's why World Bank insisted developing economies to speed up the deepening process of their local bond markets enough before the financial crises in Russia, Asia, and Latin America in 1990's (Thumrongvit et al., 2013b).

We can infer that differences in the financial markets' composition and institutions do matter, as these three major sections - bond market, stock market, and banks- do not develop and grow simultaneously, but at a different level of their growth they complement each other. Our findings are consistent with existing studies, suggesting that inter-dependency exists between financial sector and real sector technologies, which in turn determines the effect of the financial sector growth on the GDP growth. These findings could serve as additional guidance for macro-prudential policy regulations.

The outcomes of this paper suggest several promising directions for future research. First, it would be interesting to test the nexus between the financial and real sector technologies and economic growth for the panel of different countries. In addition, the effect of financial market development, following sudden changes in the political regime, would be interesting to study. Finally, conditional on the availability of appropriate forecasting techniques (see Gadea-Rivas \& Pérez-Quirós, 2015), technological progress in different other sectors could be used as a predictor of recessions.

\section{References}

Abbas, S. M. A., \& Christensen, J. E. (2010). The Role of Domestic Debt Markets in Economic Growth: An Empirical Investigation for Low-Income Countries and Emerging Markets. IMF Staff Papers, 57(1), 209-255. https://doi.org/10.1057/imfsp.2009.24

Aghion, P., Howitt, P., \& Mayer-Foulkes, D. (2005). The effect of financial development on convergence: theory and evidence. The Quarterely Journal of Economics, (February), 173-222. https://doi.org/10.1162/qjec.2005.120.1.173

Allen, F., \& Carletti, E. (2006). Credit risk transfer and contagion. Journal of Monetary Economics, 53(1), 89-111. https://doi.org/10.1016/j.jmoneco.2005.10.004

Ang, J. B. (2011). Financial development, liberalization and technological deepening. European Economic Review, 55(5), 688-701. https://doi.org/10.1016/j.euroecorev.2010.09.004

Arcand, J.-L., Berkes, E., \& Panizza, U. (2012). Too Much Finance? Journal of Economic Growth, 20(2), 105-148. https://doi.org/10.5089/9781475504668.001

Beck, T., Degryse, H., \& Kneer, C. (2014). Is more finance better? Disentangling intermediation and size effects of financial systems. Journal of Financial Stability, 10(1), 50-64. https://doi.org/10.1016/j.jfs.2013.03.005

Beck, T., \& Demirgüç-Kunt, A. (2009). Financial Institutions and Markets across Countries and over Time -Data and Analysis. Mimeo, (May), 1-42. https://doi.org/10.1596/1813-9450-4943

Ben Gamra, S. (2009). Does financial liberalization matter for emerging East Asian economies growth? Some new evidence. International Review of Economics and Finance, 18(3), 392-403. https://doi.org/10.1016/j.iref.2008.09.004

Ben Jedidia, K., Boujelbène, T., \& Helali, K. (2014). Financial development and economic growth: New 
evidence from Tunisia. Journal of Policy Modeling, 36(5), 883-898. https://doi.org/10.1016/j.jpolmod.2014.08.002

Bencivenga, V. R., \& Smith, B. D. (1991). Financial Intermediation and Endogenous Growth. The Review of Economic Studies, 58(2), 195-209. https://doi.org/10.2307/2297964

Bjellerup, M., \& Shahnazarian, H. (2012). The Interaction Between the Financial Sector and the Real Economy.

Bolton, P., Santos, T., \& Scheinkman, J. (2011). Cream Skimming in Financial Markets. National Bureau of Economic Research Working Paper Series. https://doi.org/10.2139/ssrn.1770065

Calderón, C., \& Liu, L. (2003). The direction of causality between financial development and economic growth. Journal of Development Economics, 72(1), 321-334. https://doi.org/10.1016/S0304-3878(03)00079-8

Calvet, L. E., Gonzalez-Eiras, M., \& Sodini, P. (2004). Financial innovation, market participation, and asset prices. Journal of Financial and Quantitative Analysis, 39(3), 431-459. https://doi.org/10.1017/S0022109000003975

Cecchetti, S. G., \& Kharroubi, E. (2012). Reassessing the impact of finance on growth. BIS Working Paper, (February), 1-21.

David, B., Gerhard, F., \& Fink, P. (2014). The Financial-Real Sector Nexus: Theory and Empirical Evidence. Research Institute for European Affairs, (100), 1-72. https://doi.org/10.1111/j.1475-4932.1987.tb00650.x

Dehkordi, S. R., Samerti, M., \& Dehkordi, S. R. (2012). Analyzing the Long run Interrelation between Banking System and Real Sector Function in Iran Economic through Simulation of Capital Adequacy Index. Economics and Finance Review, 2(6), 68-76.

Deidda, L., \& Fattouh, B. (2002). Non linearity between finance and growth. Economics Letters, 74(3), 339-345.

Ductor, L., \& Grechyna, D. (2015). Financial development, real sector, and economic growth. International Review of Economics and Finance, 37, 393-405. https://doi.org/10.1016/j.iref.2015.01.001

Durlauf, S. N., Johnson, P. A., \& Temple, J. R. W. (2005). Chapter 8 Growth Econometrics (pp. 555-677). https://doi.org/10.1016/S1574-0684(05)01008-7

Engle, R. F. (1982). Autoregressive Conditional Heteroscedasticity with Estimates of the Variance of United Kingdom Inflation. Journal of Economatric Society, 50(4), 987-1007. https://doi.org/10.1017/CBO9781107415324.004

Gadea-Rivas, M. D., \& Pérez-Quirós, G. (2012). The Failure to Predict the Great Recession. The Failure of Academic Economics? A View Focusing on the Role of credit. CEPR Discussion Paper Series, (9269).

Gai, P., Kapadia, S., Millard, S., \& Perez, A. (2008). Financial innovation, macroeconomic stability and systemic crises. Economic Journal, 118(527), 401-426. https://doi.org/10.1111/j.1468-0297.2007.02127.x

Gennaioli, N., Shleifer, A., \& Vishny, R. (2012). Neglected risks, financial innovation, and financial fragility. Journal of Financial Economics, 104(3), 452-468. https://doi.org/10.1016/j.jfineco.2011.05.005

Gonzalez-Eiras, M. (2003). Banks' Liquidity Demand in the Presence of a Lender of Last Resort (pp. 1-35).

Granger, C. W. J. (1969). Investigating Causal Relations by Econometric Models and Cross-spectral Methods. Econometrica, 37(3), 424. https://doi.org/10.2307/1912791

Greenwood, J., Sanchez, J. M., \& Wang, C. (2010). Financing Development: The Role of Information Costs. The Federal Reserve Bank of Richmond, Working Pa.

Jappelli, T., \& Pagano, M. (1994). Savings, Growth, and Liquidity Constraints. The Quarterely Journal of Economics, 109(1), 83-109.

Kaminsky, G. L., \& Reinhart, C. M. (1999). The Twin Crisis: The Causes of Banking and Balance-of-Payment Problems. American Economic Review, Vol., 89(3), 473-500. https://doi.org/10.1257/aer.89.3.473

King, R., \& Levine, R. (1993). Finance and Growth Schumpter Might Be Right. The Quarterly Journal of Economics, 108(3), 717-737. https://doi.org/10.2307/2118406

Kutan, A. M., Muradoglu, G., \& Sudjana, B. G. (2012). IMF programs, financial and real sector performance, and the Asian crisis. Journal of Banking and Finance, 36(1), 164-182. https://doi.org/10.1016/j.jbankfin.2011.06.015

Law, S. H., \& Singh, N. (2014). Does too much finance harm economic growth? Journal of Banking and Finance, 41(1), 36-44. https://doi.org/10.1016/j.jbankfin.2013.12.020 
Levine, R. (2000). International Financial Liberalization and Economic Growth. Review of International Economics, 612-626.

Levine, R., Loayza, N., \& Beck, T. (2000). Financial intermediation and growth: Causality and causes. Journal of Monetary Economics, 46(1), 31-77. https://doi.org/10.1007/s10258-009-0035-y

Loayza, N., \& Ranciere, R. (2006). Financial Development, Financial Fragility, and Growth. Journal of Money, Credit and Banking, 38(4). https://doi.org/10.1596/1813-9450-3431

Lucas, R. E. (1988). On the mechanics of economic development. Journal of Monetary Economics, 22(1), 3-42. https://doi.org/10.1016/0304-3932(88)90168-7

Manganelli, S., \& Popov, A. (2013). Financial dependence, global growth opportunities, and growth revisited. Economics Letters, 120(1), 123-125. https://doi.org/10.1016/j.econlet.2013.04.001

Maskus, K. E., Neumann, R., \& Seidel, T. (2005). How National and International Financial Development Affect Industrial R\&D. ETH Zurich, Department of Management, Technology, and Economics.

Masten, A. B., Coricelli, F., \& Masten, I. (2008). Non-linear growth effects of financial development: Does financial integration matter? Journal of International Money and Finance, 27(2), 295-313. https://doi.org/10.1016/j.jimonfin.2007.12.009

Murphy, K., Shleifer, M. ., \& Vishny, R. . (1991). The Allocation of Talent: Implications for Growth. The Quarterely Journal of Economics, 106(2), 503-530. Retrieved from http://www.jstor.org/journals/mitpress.html

Oluwafemi, S. A., \& Olufemi, A. A. (2015). Relevance of Financial Sector Development on Real Sector Productivity: 21 st Century Evidence from Nigerian Industrial Sector. International Journal of Academic Research in Business and Social Sciences, 5(6), 118-132. https://doi.org/10.6007/IJARBSS/v5-i6/1661

Owen, A. L., \& Temesvary, J. (2014). Heterogeneity in the growth and finance relationship: How does the impact of bank finance vary by country and type of lending? International Review of Economics and Finance, 31, 275-288. https://doi.org/10.1016/j.iref.2014.02.007

Philippon, T. (2010). Financiers vs. Engineers: Should the Financial Sector be Taxed or Subsidized? American Economic Journal: Macroeconomics, 2(3), 158-182.

Raghuram, G. R., \& Zingales, L. (1998). Financial Dependence and Growth. The American Economic Review, 88(3), 559-586. Retrieved from http://siteresources.worldbank.org/INTEXPCOMNET/Resources/Rajan_and_Zingales_1998.pdf

Rioja, F., \& Valev, N. (2004). Finance and the Sources of Growth At Various Stages of Economic Development. Economic Inquiry, 42(1), 127-140. https://doi.org/10.1093/ei/cbh049

Romer, P. M. (1986). Increasing Returns and Long-Run Growth. The Journal of Political Economy, 94(5), 1002-1037. https://doi.org/10.1086/261420

Rousseau, P. L., \& Wachtel, P. (2011). What is happening to the impact of financial deepening on economic growth? Economic Inquiry, 49(1), 276-288. https://doi.org/10.1111/j.1465-7295.2009.00197.x

Saint-Paul, G. (1992). Technological choice, financial markets and economic development. European Economic Review, 36(4), 763-781. https://doi.org/10.1016/0014-2921(92)90056-3

Samargandi, N., Fidrmuc, J., \& Ghosh, S. (2015). Is the Relationship Between Financial Development and Economic Growth Monotonic? Evidence from a Sample of Middle-Income Countries. World Development, 68(1), 66-81. https://doi.org/10.1016/j.worlddev.2014.11.010

Santomero, A. M., \& Seater, J. J. (2000). Is There an Optimal Size for the Financial Sector? Journal of Banking \& Finance, 24(6), 945-965. https://doi.org/10.1016/S0378-4266(99)00113-2

Solow, R. M. (1956). A Contribution to the Theory of Economic Growth. Source: The Quarterly Journal of Economics, 70(1), 65-94. https://doi.org/10.2307/1884513

Stiglits, J. E. (1999). Reforming the Global Economic Architecture: Lessons from Recent Crises. The Journal of Finance, 1508-1521.

Thumrongvit, P., Kim, Y., \& Pyun, C. S. (2013a). Linking the missing market: The effect of bond markets on economic growth. International Review of Economics and Finance, 27, 529-541. https://doi.org/10.1016/j.iref.2013.01.008 
Thumrongvit, P., Kim, Y., \& Pyun, C. S. (2013b). Linking the missing market: The effect of bond markets on economic growth. International Review of Economics and Finance, 27, 529-541. https://doi.org/10.1016/j.iref.2013.01.008

Wagner, W. (2007). The liquidity of bank assets and banking stability. Journal of Banking and Finance, 31(1), 121-139. https://doi.org/10.1016/j.jbankfin.2005.07.019

Williams, J., \& Nguyen, N. (2005). Financial liberalisation, crisis, and restructuring: A comparative study of bank performance and bank governance in South East Asia. Journal of Banking and Finance, 29(8-9 SPEC. ISS.), 2119-2154. https://doi.org/10.1016/j.jbankfin.2005.03.011

Zeira, J. (1999). Informational overshooting, booms, and crashes. Journal of Monetary Economics, 43, 237-257. https://doi.org/10.1016/S0304-3932(98)00042-7

\section{Appendix}

Table 1. Results of Augmented Dickey-Fuller Test (ADF)

\begin{tabular}{lccc}
\hline Variables & t-Statistics & Probability & Conclusion \\
\hline GDP & $-10.80^{* *}$ & 0.0000 & I $(1)$ \\
BONDS & $-4.15^{* *}$ & 0.0013 & $\mathrm{I}(1)$ \\
LOANS & $-7.58^{* *}$ & 0.0000 & $\mathrm{I}(1)$ \\
MKTCAP & $-6.77^{* *}$ & 0.0000 & $\mathrm{I}(1)$ \\
\hline
\end{tabular}

Note. The null hypothesis is that the series is non-stationary, or contains a unit root. The rejection of null hypothesis for ADF test is based on **1\% level of significance by AIC criteria.

Table 2. Unrestricted co-integration rank test (Maximum Eigenvalue)

\begin{tabular}{ccccc}
\hline $\begin{array}{c}\text { Hypothesized } \\
\text { No. of CE(s) }\end{array}$ & Eigenvalue & $\begin{array}{c}\text { Max-Eigen Statistics } \\
\text { Statistics }\end{array}$ & $\begin{array}{c}\boldsymbol{0 . 0 5} \\
\text { Critical Value }\end{array}$ & Prob.** \\
\hline None * & 0.274 & 29.530 & 27.584 & 0.027 \\
At most 1 & 0.228 & 23.918 & 21.131 & 0.019 \\
At most 2 & 0.107 & 10.393 & 14.264 & 0.187 \\
At most 3 & 0.021 & 2.023 & 3.841 & 0.154 \\
\hline
\end{tabular}

Note. Max-Eigenvalue test specifies 2 co-integrating eqn.(s) at the 0.05 level

* denotes rejection of the hypothesis at the 0.05 level; **MacKinnon-Haug-Michelis (1999) p-values.

Table 3. Normalized co-integrating coefficients: 1 co-integrating Equation(s)

\begin{tabular}{cccc}
\hline $\boldsymbol{G D P}$ & \multicolumn{3}{c}{1.00} \\
\hline & Coefficients Standard & Standard Error & t-statistics \\
\hline BONDS & 0.177 & 0.060 & 2.95 \\
MKTCAP & 0.038 & 0.019 & 2.00 \\
LOANS & 0.091 & 0.058 & 1.56 \\
\hline
\end{tabular}

Table 4. Results of error correction model

\begin{tabular}{lcc}
\hline Dependent Variable $=$ GDP & & \\
\hline Independent Variable & Coefficients & t-statistics \\
\hline Constant & 0.00 & 0.84 \\
D(GDP(-1)) & -0.01 & -0.13 \\
D(GDP(-2)) & 0.18 & 1.27 \\
D(GDP(-3)) & 0.08 & 0.63 \\
D(GDP(-4)) & 0.12 & 1.03 \\
D(GDP(-5)) & 0.17 & 1.52 \\
D(BONDS(-1)) & -0.01 & -0.58 \\
D(BONDS(-2)) & 0.01 & 0.45 \\
D(BONDS(-3)) & -0.01 & -0.65 \\
D(BONDS(-4)) & -0.03 & -1.30 \\
D(BONDS(-5)) & -0.07 & -2.79 \\
\hline
\end{tabular}




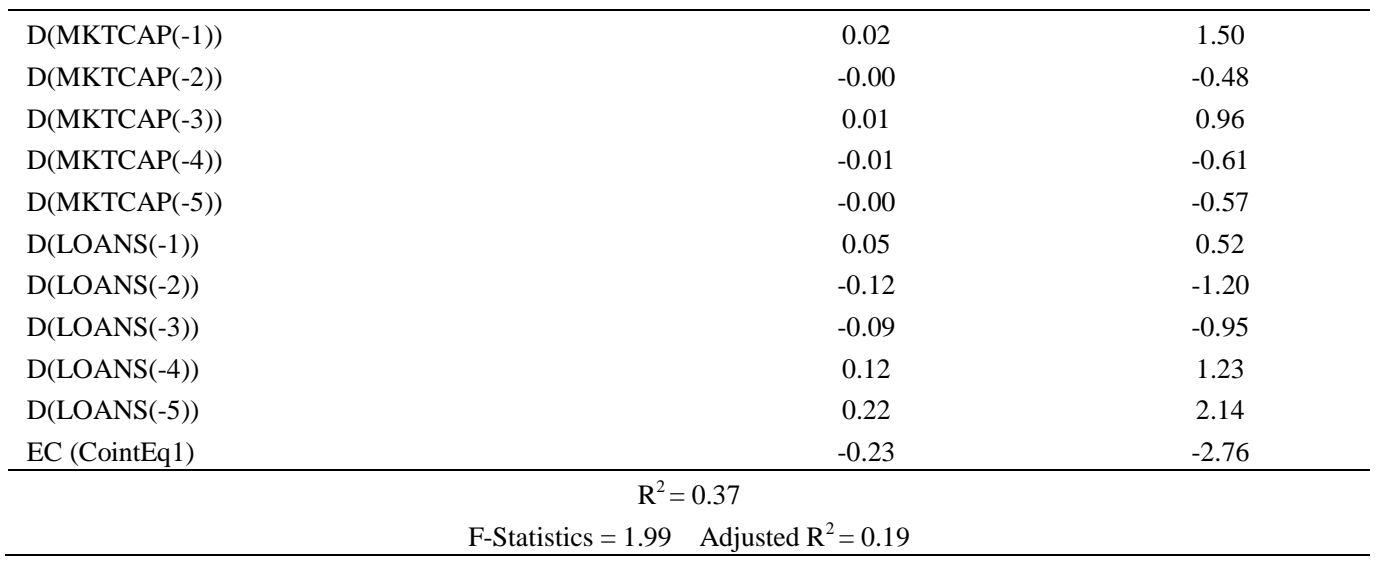

Table 5. Granger causality test

\begin{tabular}{lcc}
\hline Null Hypothesis: & F-Statistic & Prob. \\
\hline BONDS does not Granger Cause GDP & 2.165 & 0.001 \\
GDP does not Granger Cause BONDS & 0.456 & 0.318 \\
MKTCAP does not Granger Cause GDP & 2.854 & 0.086 \\
GDP does not Granger Cause MKTCAP & 1.836 & 0.132 \\
LOANS does not Granger Cause GDP & 1.179 & 0.851 \\
GDP does not Granger Cause LOANS & 4.041 & $3 . \mathrm{E}-09$ \\
MKTCAP does not Granger Cause BONDS & 1.774 & 0.122 \\
BONDS does not Granger Cause MKTCAP & 2.729 & 0.004 \\
LOANS does not Granger Cause BONDS & 1.947 & 0.436 \\
BONDS does not Granger Cause LOANS & 3.481 & $3 . \mathrm{E}-05$ \\
LOANS does not Granger Cause MKTCAP & 0.800 & 0.395 \\
MKTCAP does not Granger Cause LOANS & 4.446 & 0.003 \\
\hline
\end{tabular}

Table 6. GARCH process

\begin{tabular}{|c|c|c|c|c|}
\hline \multicolumn{5}{|c|}{ Dependent Variable: D(GDP) } \\
\hline \multicolumn{5}{|c|}{ Method: ML - ARCH (Marquardt) - Normal distribution } \\
\hline \multicolumn{5}{|c|}{ Sample (adjusted): 1993Q3 2017Q2 } \\
\hline \multicolumn{5}{|c|}{ Included observations: 96 after adjustments } \\
\hline \multicolumn{5}{|c|}{ Convergence achieved after 71 iterations } \\
\hline \multicolumn{5}{|c|}{ Presample variance: backcast $($ parameter $=0.7$ ) } \\
\hline Variable & Coefficient & Std. Error & z-Statistic & Prob. \\
\hline \multicolumn{5}{|c|}{ Variance Equation } \\
\hline $\mathrm{C}$ & $1.42 \mathrm{E}+09$ & 4.64E+08 & 3.072737 & 0.0021 \\
\hline $\operatorname{RESID}(-1)^{\wedge} 2$ & 0.294486 & 0.119961 & 2.454858 & 0.0141 \\
\hline GARCH(-1) & -0.116023 & 0.088298 & -1.313988 & 0.1889 \\
\hline $\mathrm{D}(\mathrm{BONDS})$ & 440.7658 & 2061.457 & 0.213813 & 0.8307 \\
\hline D(MKTCAP) & -301.5612 & 211.8304 & -1.423597 & 0.1546 \\
\hline D(LOANS) & -789.0988 & 1862.573 & -0.423661 & 0.6718 \\
\hline R-squared & -0.202968 & Mean dependent var & & 15502.30 \\
\hline Adjusted R-squared & -0.190437 & S.D. dependent var & & 34590.44 \\
\hline S.E. of regression & 37740.64 & Akaike info criterion & & 23.80361 \\
\hline Sum squared resid & $1.37 \mathrm{E}+11$ & Schwarz criterion & & 23.96388 \\
\hline Log likelihood & -1136.573 & Hannan-Quinn criter. & & 23.86839 \\
\hline Durbin-Watson stat & 1.817268 & & & \\
\hline
\end{tabular}

\section{Copyrights}

Copyright for this article is retained by the author(s), with first publication rights granted to the journal.

This is an open-access article distributed under the terms and conditions of the Creative Commons Attribution license (http://creativecommons.org/licenses/by/4.0/). 